\title{
Growth, dry matter production of avocado (Persea americana Mill.) seedlings and soil physico- chemical properties as affected by organic and inorganic nutrient sources
}

\section{A. HAILEAB}

AUTHOR FOR CORRESPONDENCE:

A. HAILEAB

Ambo University, AMBO, ETHIOPIA

Email: haileshye2011@yahoo.com
Received : 31.08.2016; Revised : 16.10.2016; Accepted : 11.11 .2016

\section{Summary}

A lath house trial involving four doses of inorganic $\mathrm{N}$ and $\mathrm{P}$ and six types of organic potting materials was undertaken in the Jimma Agricultural Research Centre in the year 2011 to determine the effect of organic and inorganic nutrient sources on the soil physico-chemical properties, growth and dry matter production of avocado seedlings. Four levels of inorganic $\mathrm{N}$ and $\mathrm{P}\left(\mathrm{N}_{0} \mathrm{P}_{0}, \mathrm{~N}_{150} \mathrm{P}_{200}, \mathrm{~N}_{300} \mathrm{P}_{400}\right.$ and $\mathrm{N}_{450} \mathrm{P}_{600} \mathrm{mg} /$ pot $)$ as the first factor and five organic materials, FYM (farmyard manure), FD (farmyard manure mixed with decomposed coffee husk), DCH (decomposed coffee husk), UCH (un decomposed coffee husk) and UF (un decomposed coffee husk mixed with farmyard manure), including TS (Top soil) as the second factor were evaluated in a Randomized Complete Block Design with three replications. Avocado shoot (plant height, stem girth, number of leaves and leaf area) and root growths (root girth, primary root length and lateral root length) were significantly ( $\mathrm{p}<0.01$ or $\mathrm{p}<0.05)$ affected by the independent effect of organic and inorganic nutrient sources. The lowest and highest shoot growths were recorded at $\mathrm{N}_{0} \mathrm{P}_{0}$ and $\mathrm{N}_{300} \mathrm{P}_{400}$ of fertilizer application, respectively. Most vigorous shoot growths were recorded from seedlings grown in TS:DCH (2:1) followed by (TS:FYM (2:1). Media prepared from TS: UCH (2:1) had the least avocado shoot and root growths. Seedlings grown on decomposed organic materials produced higher amount of root growth in the order: TS : FYM (2:1)>TS:FD (2:1)>TS:DCH (2:1). Media prepared from TS:UCH(2:1)+ $\mathrm{N}_{0} \mathrm{P}_{0}$ and TS:DCH $(2: 1)+\mathrm{N}_{450} \mathrm{P}_{600}$ resulted significantly the lowest and the highest shoot dry mass, respectively. TS : FYM $(2: 1)+\mathrm{N}_{300} \mathrm{P}_{400}$ produced the highest total dry matter followed by TS:DCH $(2: 1)+\mathrm{N}_{450} \mathrm{P}_{600}$. The lowest total dry matter, on the other hand, was obtained from TS:UCH (2:1) $+\mathrm{N}_{0} \mathrm{P}_{0}$ Decomposed organic materials incorporated into the growing media had significantly improved the water holding capacity of the media at both the permanent and field capacity. The decomposed organic materials, in particular, had a positive influence on most chemical properties considered during the study (Total $\mathrm{N}$, available $\mathrm{P}$, Organic carbon, $\mathrm{pH}, \mathrm{CEC}$ and $\mathrm{EC}$ ).With the increase in the rate of application of inorganic NP fertilizers, the $\mathrm{pH}$ and EC of the growing media had accordingly decreased; Total $\mathrm{N}$ and available $\mathrm{P}$, on the other hand, had improved. Apart from independent effects, the electrical conductivity of the growing media was also significantly affected by the interaction of organic and inorganic source of fertilizers. In conclusion, most vigorous avocado seedlings under lath house condition was obtained by amelioration of the growth media using TS : $\mathrm{FYM}(2: 1)+\mathrm{N}_{300} \mathrm{P}_{400}$ followed by TS: DCH $(2: 1)$ $+\mathrm{N}_{450} \mathrm{P}_{600}$. 